https://doi.org/10.31470/2706-7904-2020-15-234-237

\title{
СУТНІСТЬ ТА ОСОБЛИВОСТІ ВИКОРИСТАННЯ \\ ПАРАЛЕЛЬНИХ КОРПУСІВ ПЕРЕКЛАДУ В НАВЧАННІ \\ ІНОЗЕМНИМ МОВАМ У ЗАКЛАДАХ ВИЩОЇ ОСВІТИ
}

Essence and Peculiarities of the Using of Parallel Translation Frames in Teaching of Foreign Language at Higher School

\author{
Svitlana Tanana \\ Ph.D. in Pedagogy, Assistant Professor \\ Hryhoriy Skovoroda University in Pereiaslav (Ukraine) \\ tananasvetlana@gmail.com \\ https://orcid.org/0000-0002-6088-0738
}

\begin{abstract}
The article deal with the using of parallel frames of translations in the educational process is one of the effective means of increasing the level of foreign language communicative competence of specialists in foreign languages and translation. The particular means $l$ is especially important for independent work and distance learning. The author accents with the help of parallel corpora of translations, the student, finding the appropriate equivalent of the lexical unit, can draw conclusions about the principle of translation of proper and geographical names (transcription, transliteration), idioms, terms, find matches for certain grammatical and stylistic phenomena.
\end{abstract}

Keywords: parallel frames of translations, distance learning, foreign languages, grammatical and stylistic phenomena.

\section{Ветуп \\ Introduction}

Сучасна перекладацька парадигма давно вийшла за рамки лінгвістичної теорії перекладу i ефективно розвивається як міждисциплінарний напрямок, дозволяючи інкорпорувати досягнення літературознавства, семіотики, культурології для вирішення певних завдань. Актуальність теми статті зумовлена тенденцією останніх лінгвістичних розробок щодо багатоаспектного аналізу використання пералельних корпусів перекладу під час навчання іноземної мови у ЗВО. Досягти успішного перекладу перекладачеві допомагає чітко напрацьована стратегія перекладу.

Оновлення та інновації освіти на сучасному етапі розвитку України вимагають включення в освітній процес технологічних нововведень, змін організаційної сторони 
навчального процесу й супроводжуються багаторівневою перебудовою освітнього процесу. Стійка тенденція до зростання ролі іноземної мови у всіх сферах життя людини в сучасному суспільстві диктує новий підхід до навчання іноземним мовам, формування нового погляду на місце зарубіжної культури в освітньому процесі. Одним із сучасних засобів навчання іноземної мови та перекладу є використання в освітньому процесі корпусів паралельних перекладів.

Останніми роками розгляду цієї проблеми був присвячений ряд праць таких сучасних дослідників, як Н.П. Дарчук, Ю.І. Дем’ячук, Н.О. Лангенбах, С.А. Матвеєвої, В.М. Сорокіна, Є.П. Сосніної, Я.В. Ходаківської, М.О. Шведової. Незважаючи на активний розвиток корпусної лінгвістики в Україні, багато аспектів цієї науки залишаються недостатньо вивченими, що обумовлює актуальність нашої розвідки.

Мета дослідження - здійснити науково обгрунтований аналіз використання паралельних корпусів перекладів у процесі навчанні іноземним мовам та перекладу здобувачів освіти у ЗВО.

\section{Методи та методики дослідження Methods and Techniques of the Research}

Для досягнення зазначеної мети були використані наступні теоретичні методи і методики: дедуктивний як шлях від абстрактного до конкретного; індуктивний як узагальнення фактів; контент-аналіз. Також використовувалися інтерпретаційні методи, що грунтуються на конкретних принципах системного, діяльнісного, когнітивного, психолінгвістичного підходів. Вони спрямовані на пояснення отриманих результатів із точки зору первинних припущень та посилань.

\section{Результати \\ Results}

Зазначимо, що застосування паралельних корпусів перекладів у навчанні іноземним мовам та перекладу $є$ одним із дієвих засобів підвищення іноземної комунікативної компетенції здобувачів освіти. Паралельні корпуси перекладу дозволяють швидко підібрати можливі еквіваленти іноземної лексики, що вивчається, прослідкувати їх значення та функції в тих чи інших контекстах. Як слушно зауважує М. Шведова, за їх допомогою можна «швидко отримувати велику кількість реальних перекладацьких рішень, що були прийняті носіями мови при створенні перекладу, й аналізувати виявлені відповідники в лексиці та граматиці, досліджувати перекладні моделі» (Шведова 2013, 100). 
Звернімо увагу на той факт, що у практичному значенні переклад повинен орієнтуватися на можливості постредагування, порівняння та оцінку різноманітних стратегій й інтерпретацій у рамках контексту. Перекладачу, особливо початківцю, необхідні ресурси, які можуть слугувати еталоном перекладу і оцінці перекладу в тих чи інших «стандартних» умовах. Значна кількість часу перекладача витрачається на звернення до реферативної інформації, наприклад словників. Електронні паралельні корпуси перекладів та лінгвістичні комп’ютерні технології дозволяють скоротити ці витрати часу та надають зразки професійного перекладу при вивченні прийомів $\mathrm{i}$ способів перекладу.

Перекладач отримує інструмент для швидкого аналізу мовної одиниці та варіантів іiї перекладу із залученням великого масиву текстової та екстралінгвістичної інформації з одночасним зануренням у контекст. Паралельний корпус перекладів дозволяє проводити порівняння не лише тексту оригіналу та його перекладу, а й навпаки - порівнювати текст перекладу з оригіналом.

Водночас, при використанні паралельних корпусів перекладів слід застосовувати критичний підхід у кожному окремому випадку, адже існує проблема наявності помилок, невдалого вибору перекладацьких відповідників, низької лінгвістичної якості текстів тощо (Ніколаєва, 2018: 110).

\section{Висновки \\ Conclusions}

Використання паралельних корпусів перекладів в освітньому процесі є одним 3 ефективних засобів підвищення рівня іншомовної комунікативної компетенції фахівців з іноземної мови та перекладу. Особливого значення цей засіб набуває при самостійній роботі та в умовах дистанційного навчання.

Таким чином, за допомогою паралельних корпусів перекладів здобувач освіти, знайшовши відповідний еквівалент лексичної одиниці, має змогу зробити висновок щодо принципу перекладу власних та географічних назв (транскрипція, транслітерація), ідіом, термінів тощо, знайти відповідники певним граматичним та стилістичним явищам, отримавши список контекстів для певного явища.

\section{Література \\ References}

Ніколаєва, Т.М. (2018). Перекладацькі стратегії в англо-українському просторі. Вчені записки Таврійського національного університету імені В.І. Вернадського. Серія: Філологія. Сочіальні комунікації, 29(1), 110-115. 
Psycholinguistics in a Modern World - 2020. Proceedings of the 15th International Scientific and Practical Conference (Pereiaslav-Khmelnytskyi, 22-23 October, 2020)

Шведова, М.О. (2013). Корпусна лінгвістика та лексико-граматична типологія: Українське мовознавство, 43, 95-103.

EN 15038: 2006 (2006). Translation Services - Service requirements. Brussels: Technical Committee ISO/TC37. Retrieved October 6, 2020 from qualitystandard.bs.en-15038.com

ISO 17100:2015 (2015). Translation Services - Requirements for Translation Services. Brussels: European Committee for Standardization._Retrieved October 8, 2020 from www.iso.org

Venuti, L. (2001). Strategies of translation. Rout-ledge encyclopetia of translation studies (pp. 240244). London: Taylor and Francis Books Ltd. 